NBER WORKING PAPER SERIES

\title{
THE IMPACT OF STATE TAXES ON SELF-INSURANCE
}

\author{
Bin Ke \\ Kathy R. Petroni \\ Douglas A. Shackelford \\ Working Paper 7453 \\ http://www.nber.org/papers/w7453 \\ NATIONAL BUREAU OF ECONOMIC RESEARCH \\ 1050 Massachusetts Avenue \\ Cambridge, MA 02138 \\ December 1999
}

This paper has benefited from workshop participants at the University of North Carolina and Stanford University. The views expressed herein are those of the authors and not necessarily those of the National Bureau of Economic Research.

(C) 1999 by Bin Ke, Kathy R. Petroni, and Douglas A. Shackelford. All rights reserved. Short sections of text, not to exceed two paragraphs, may be quoted without explicit permission provided that full credit, including (C) notice, is given to the source. 
The Impact of State Taxes on Self-Insurance

Bin Ke, Kathy R. Petroni and Douglas A. Shackelford

NBER Working Paper No. 7453

November 1999

JEL Nos. H22, H25, G22, D12

\section{$\underline{\text { ABSTRACT }}$}

This paper assesses whether insurers' state taxes reduce purchases of property-casualty coverage. Tests are conducted using state aggregates of insurer-level data from publicly-available, annual accounting reports for 1993, 1994, and 1995. A positive relation between self-insurance and state taxes is detected, consistent with consumers opting to self-insure rather than bear the incidence of higher insurer taxes. The primary empirical estimates imply that a 1 percent increase in the state premium tax rate reduces non-automobile insured losses by 0.18 percent to 0.28 percent. These elasticities suggest that for the mean state, a standard deviation increase in the state tax rate $(0.5$ percent) would lower insured losses by approximately $\$ 140$ million or 7.5 percent of current coverage. As expected, tax effects vary with the elasticity of demand. When demand is largely inelastic, e.g., automobile liability coverage, taxes do not affect self-insurance.

Bin Ke

Penn State University

203 Beam Building

University Park, PA 16802-1912

bxk127@psu.edu

Douglas A. Shackelford

University of North Carolina

Campus Box 3490

Chapel Hill, NC 27599-3490

and NBER

doug_shack@unc.edu
Kathy Petroni

Michigan State University

N270 North Business Complex

East Lansing, MI 48824-1122

petroni@ pilot.msu.edu 


\section{The Impact of State Taxes on Self-Insurance}

\section{Introduction}

This paper assesses whether insurers' state taxes reduce purchases of property-casualty insurance coverage in a state. Insurance rates should be higher in states with higher taxes, assuming the demand curve for insurance is not perfectly elastic. Consequently, consumers should self-insure more in those states. Self-insurance includes forgoing insurance completely, purchasing lower levels of coverage, or accepting higher deductibles.

To test the proposition that self-insurance is increasing in state insurer taxes, all propertycasualty insured losses in each state are regressed on insurers' total taxes in that state. Publiclyavailable, annual accounting reports, which all insurers must file with state regulators, provide the data from which aggregated state insured losses are computed. Tests are conducted separately for 1993, 1994, and 1995.

The dependent variable is designed to capture the extent to which consumers shift property-casualty risks to insurance companies. Unfortunately, risks (or coverage or selfinsurance) are unobservable. One possible proxy for insurance coverage is premiums. We use insured losses, instead of premiums, to measure coverage because Petroni and Shackelford (1999) report that insurers understate (overstate) the premiums earned in states that apply a higher (lower) premium tax rate. Because the premium tax, which is the primary state tax, is levied on insurers' gross receipts, insured losses do not affect the premium tax liability. Unlike losses, premiums are further biased because they are reported inclusive of the premium tax. Therefore, insured losses should provide a less biased measure of insurance coverage than premiums. To control for unanticipated losses, the regression's explanatory variables include an 
estimate of catastrophic damage in the state. We also control for other potential sources of crossstate claim variation, such as population and wealth.

Besides the usual research limitations, such as measurement error and inadequate power, this paper may fail to detect a relation between self-insurance and taxes for at least two reasons. First, tax plans may fully eradicate cross-state tax variation. Slemrod (1996), Grubert and Slemrod (1996), Shackelford (1999), and Olhoft (1999), among others, model tax planning as continuing until the costs of tax planning exceed the taxes avoided. Slemrod $(1990,1992)$ constructs a hierarchy of tax avoidance where firms undertake relatively low-cost accounting and financial tax plans that exploit subtle legal distinctions to prevent taxes from affecting their production and marketing ("real" responses). Consistent with these models, extant studies document that property-casualty insurers make seemingly low-cost accounting and organizational choices that reduce their state taxes. ${ }^{1}$ If successful, these tax avoidance strategies may eliminate cross-state statutory tax differences and prevent taxes from differentially affecting pricing decisions. If so, state taxes should not differentially affect insurance rates or selfinsurance.

The second reason that no relation may be detected is that the demand for at least some forms of coverage may approach perfect inelasticity. If so, insurance rates will vary across states, but coverage will not vary. For example, automobile liability coverage is compulsory in 39 states. That is, consumers must choose between coverage and forgoing legal operation of an automobile. As a result, the demand curve for automobile liability coverage likely approaches

\footnotetext{
${ }^{1}$ Specifically, Petroni and Shackelford [1995] report that property-casualty insurers expand from subsidiaries incorporated in states with lower premium tax rates to avoid the higher "retaliatory" taxes assessed on insurers that write policies outside their state of incorporation. Petroni and Shackelford (1999) find that property-casualty insurers that write multistate policies allocate in their annual accounting reports disproportionate premiums from those policies to states with lower premium tax rates.
} 
vertical in compulsory states.

Consistent with downward sloping demand curves, we find property-casualty insured losses in lines, other than automobile, are decreasing in insurers' state tax burdens. This finding is consistent with state taxes suppressing property-casualty coverage. The result implies that tax planners are unable to eliminate state tax differences fully.

Additional tests that separately evaluate the two primary classifications of automobile insurance (liability coverage and physical damage coverage) further demonstrate that the relation between taxes and self-insurance varies with the elasticity of demand. Specifically, we find no relation between taxes and automobile liability insurance coverage, consistent with price inelasticity for mandated coverage. Conversely, consistent with a downward sloping demand curve for optional coverage, we find a negative relation between taxes and automobile physical damage insurance coverage. Further confirmation that taxes affect self-insurance is provided through an examination of workers' compensation benefit payments.

To our knowledge, this is the first study to document that state taxes affect the insurance coverage in a state. The empirical link between taxes and consumer goods should aid in our understanding of the role of taxes in price formation. The paper also should interest policymakers, insurers, and consumer organizations because it calibrates the effects of industry taxes on self-insurance. For example, the primary empirical estimates imply that a 1 percent increase in the state premium tax rate reduces non-automobile insured losses by 0.18 percent to 0.28 percent. These elasticities suggest that for the mean state, a standard deviation increase in the state tax rate ( 0.5 percent) would lower insured losses by approximately $\$ 140$ million or 7.5 percent of current coverage. The results imply similar increases in self-insurance for automobile physical damage coverage, but not for automobile liability coverage. 
Caution should be exercised in interpreting the findings in this paper. Theory is not rich enough to specify fully the interplay between states, insurers and consumers. Consequently, the tests rely on several key assumptions.

The remainder of the paper is as follows: Section 2 sketches institutional background. Section 3 outlines the research design. Section 4 presents the empirical findings. Concluding remarks follow.

\section{Background}

\subsection{Premium tax}

Premium taxes are the primary state tax levied on the insurance industry. Every state taxes insurance premiums. Thirteen states also levy at least one other tax (income, franchise, privilege, or capital) on the industry.

Insurer state taxes are not trivial. The industry has paid more in state taxes than in U.S. Federal taxes in at least some years. For example, in 1990 insurers paid $\$ 7$ billion in state taxes and $\$ 5.7$ billion in Federal taxes (U.S. Department of Commerce, Bureau of the Census, State Government Tax Collections, 1992, Internal Revenue Service Statistics of Income Corporate Sourcebook, 1990, Sangha and Neubig, 1994). In addition, because the premium tax is levied on gross receipts and profit margins are thin in the insurance industry, the effective state tax rate can be substantial. For example, although this study finds that the mean and median state taxes as a percentage of premiums were only 1.6 percent in 1993, Sangha and Neubig, (1994) report that state taxes as a percentage of income was 31 percent, 24 percent, and 61 percent in 1990, 1991, and 1992, respectively. 


\subsection{Sales tax}

As a gross receipts tax, the premium tax resembles a sales tax. Accordingly, this paper is related to those in the economics literature addressing the extent to which consumers bear the incidence of the sales tax (see review in Poterba, 1996). Poterba (1996) models the price effects of the sales tax and shows that in perfect competition, consumers should bear its full burden. ${ }^{2}$ Consistent with this prediction, the sales tax studies find little evidence that retailers bear the incidence of the sales tax. In fact, Besley and Rosen (1999) report that for some goods, prices inexplicably overshift, i.e., an increase in tax revenue of one dollar per unit increases the price by more than one dollar.

The usefulness of Poterba's (1996) model for understanding the impact of insurer premium taxes on self-insurance may be limited because of structural differences in the two gross receipts taxes. Unlike the sales tax rate, which is identical for all retailers within a locale, a policy's premium tax rate varies depending on the insurer's state of incorporation. Specifically, if state i's tax rate is " and the tax rate in insurer j's state of incorporation is \$, then insurer j's premium tax rate in state $\mathrm{i}$ is the greater of " and \$. These "retaliatory" taxes favor in-state insurers and discriminate against out-of-state insurers. Because most policies are written by outof-state insurers, policies written within a single state face a range of premium tax rates. ${ }^{3}$

Sales tax analogues to within-state premium tax variation suggest some insurers may bear the incidence of the premium tax. For example, retailers are more likely to bear some tax

\footnotetext{
${ }^{2}$ Let $q(X)$ be the inverse demand curve, where $X$ is the total quantity produced by all firms, $c$ be a constant marginal cost, and $\delta$ be the sales tax. Firm i chooses $x_{i}$ to maximize $\left.Q X\right)-c-\delta \mathbf{Q}_{i}$. Assuming perfect competition, the first-order condition for profit maximization yields $q(X)=c+\delta$, i.e., retailers charge a price that covers their costs, including the entire sales tax. Assumptions of perfect competition do not appear unreasonable for the property-casualty insurance industry (Joskow, 1973; Cummins and Weiss, 1991). ${ }^{3}$ Petroni and Shackelford (1999) report that out-of-state insurers wrote 95 percent of their sample policies.
} 
incidence of the sales taxes along political borders. Theoretical and empirical studies (e.g., Mikesell, 1970, Sidhu, 1971; Gordon, 1983; Fox, 1986, Mintz and Tulkens, 1986; Braid, 1987; Rappaport, 1994, Trandel, 1994, Gordon and Neilsen, 1997, among others) are consistent with smaller retail price responses to sales tax changes along political borders. Likewise, Goolsbee (1999) reports that residents in high sales tax locations purchase more on the Internet, where sales are often not subject to sales tax. Although we are unaware of any empirical evidence, similar anecdotes have been advanced about mail-order sales, which also often escape sales taxes. In summary, the evidence suggests retailers bear some tax incidence when consumers are proximate to less heavily taxed jurisdictions or can access delivery systems (e.g., Internet or mail-order) that bypass the sales tax. These findings would imply that when consumers face multiple premium tax rates in a state, insurers bear some tax incidence.

In addition, documentation that insurers engage in premium tax avoidance is prima facie evidence that insurers believe that they could bear some tax costs. Consistent with insurers bearing state tax incidence, Petroni and Shackelford (1999) report that insurers allocate a disproportionately large percentage of the premiums from multistate policies to less heavily taxed states. To our knowledge, no study documents that retailers engage in tax plans to avoid sales taxes, consistent with retailers avoiding the incidence of the sales tax.

Finally, this study differs from the sales tax studies along a research design dimension. The sales tax studies generally assess the effect of taxes on prices and assume that quantity changes in response. ${ }^{4}$ Unfortunately, unlike the consumer goods examined in the sales tax studies, which are homogeneous and numerous (e.g., Besley and Rosen, 1999, compare the prices of thousands of Big Macs, Kleenex, and similar goods across U.S. cities), insurance

\footnotetext{
${ }^{4}$ Notable exceptions include studies of the effects of excise taxes on goods, such as cigarettes (e.g., Chaloupka, et al., 1999)
} 
policies are customized financial contracts with extensive contingencies. Thus, comparing the rates of insurance policies across states would not be a fruitful exercise.

An alternative is to compare profit margins across states, e.g., total premiums in the state divided by all costs of providing coverage in the state. Unfortunately, data limitations prevent us from observing this profit measure. Its numerator, premiums, is biased. Petroni and Shackelford (1999) document that the premiums disclosed in insurers' annual accounting reports are managed to reduce premium tax liabilities. Its denominator, total expenses, is unobservable. The only expense reported in the annual accounting reports for each state and by line of insurance is nominal incurred losses. Other expenses are segregated neither at the line of insurance level nor at the state level.

Bradford and Logue (1998) use the premium-loss ratio to measure price in their analysis of the impact of the Tax Reform Act of 1986 on the insurance industry. ${ }^{5}$ Although they are unimpeded by any cross-state shifting, they conclude that non-tax factors, such as interest rate swings, overwhelm the effect of Federal taxes on premium-loss ratios. Their inability to isolate Federal tax effects using intertemporal profit-loss ratios support the notion that profit-loss ratios lack the necessary power to calibrate the effects of state insurer taxes on self-insurance.

Consequently, we estimate the impact of state taxes on the market for property-casualty insurance by evaluating the relation because taxes and quantity, i.e., insurance coverage, as measured by incurred losses. On a more positive note, unlike the sales tax studies, which generally ignore quantity effects, this paper can address issues of social welfare concerning selfinsurance. Thus, this paper's inability to estimate tax-price relations and its focus on tax-

\footnotetext{
${ }^{5}$ As an aside, consistent with the spirit of this study, the increased industry taxes in the Tax Reform Act of 1986 were motivated partly by a perception that the industry's previously favorable Federal tax policy had provided an undesirable disincentive for self-insurance (General Accounting Office, 1995).
} 
quantity relations is not necessarily a weakness, but simply a difference from most extant sales tax literature.

\section{Research Design}

\subsection{Regression equation}

To test the proposition that self-insurance is increasing in state taxes, we estimate the following regression equation at the state-level:

$$
\operatorname{LOSS}_{i}=\beta_{0}+\beta_{1} T A X_{i}+\beta_{2} P O P_{i}+\beta_{3} W_{E A L T H}+\beta_{4} C A T_{i}+\varepsilon_{i}
$$

where $\operatorname{LOSS}_{i}$ is the property-casualty industry's insured losses in state $\mathrm{i}$; $T A X_{i}$ is the total insurance taxes collected in state $\mathrm{i}$ in the three preceding years (i.e., years $\mathrm{t}-3, \mathrm{t}-2$ and $\mathrm{t}-1$ ) divided by the total premiums earned in state $\mathrm{i}$ in the same three preceding years; $P O P_{i}$ is state i's population; $W_{E A L T H}$ is state i's gross state product per capita; and $C A T_{i}$ is state i's estimated catastrophic losses.

A negative coefficient on $T A X$ will be interpreted as evidence that the demand for property-casualty insurance is elastic, causing self-insurance to increase with state taxes. To facilitate coefficient interpretation, the model is estimated in log-linear form. ${ }^{6}$ The regression is conducted separately for 1993, 1994 and 1995. Multiple years are examined to mitigate concerns that the results are period-specific.

The model specification relies on Klassen and Shackelford's (1998) rejection of simultaneous determination of subnational tax revenues and rates. Klassen and Shackelford (1998) jointly estimate a model of U.S. state and Canadian provincial corporate income tax revenues and a model of U.S. state and Canadian provincial corporate income tax rates. They

\footnotetext{
${ }^{6}$ Zero values of $C A T$ are assigned a natural logarithmic value of zero. All other variables have positive values.
} 
find that the inferences drawn from the simultaneous equations are qualitatively indifferent from those drawn from ordinary least squares.

Consequently, this paper assumes states exogenously levy taxes on the insurance industry, and insurers and consumers endogenously make decisions that determine the taxes paid. However, to the extent Klassen and Shackelford's findings do not generalize to the state insurer tax setting and simultaneity exists, the determinants of tax rates could be correlated with the factors affecting coverage. If so, ordinary least square estimates of equation (1) could produce erroneous inferences.

One similarity between the corporate income taxes that Klassen and Shackelford (1998) examine and the insurer taxes in this study is that in both settings, tax rates change very infrequently. Thus, even if rates were originally set in response to factors affecting coverage, such as cross-state differences in risk preferences, those factors may now be relatively unimportant. For example, the current discriminatory state taxes levied on out-of-state insurers date back to the 1800 s when southern and western states attempted to soak the industry, which at that time was predominantly located in northeastern states.

\subsection{Dependent variable}

The dependent variable is designed to measure insurance coverage. As discussed above, premiums are not an option for the dependent variable because insurers manage the premiums they report to each state to reduce overall premium tax liabilities (Petroni and Shackelford, 1999). In other words, because insurers underreport the premiums earned in high-tax states, premiums would induce a negative relation between the dependent variable and taxes, biasing toward rejecting the null hypothesis. 
To avoid this bias, the study employs total insured losses, which are expected to suffer less manipulation than premiums for two reasons. First, insurers have little incentive to allocate insured losses across states for tax purposes. Unlike premiums, losses are irrelevant for purposes of computing the premium tax base. Although losses are included in income tax bases, only seven states tax insurers' income. ${ }^{7}$ If insurers do overstate losses in high income tax states, the tests are biased against rejecting the null hypothesis.

Second, although losses presumably affect regulators' assessments of an insurer's solvency and profitability, insurers are less likely to manage losses for regulatory purposes than to manage premiums. Regulators can observe the state in which a loss occurs more easily than the state in which a premium is earned. For example, hurricane damage in Florida may be impossible to report as a claim arising in another state. However, the policy covering property in Florida also may cover property in other states. As a result, premiums provide more sourcing ambiguity, which facilitates insurers' opportunistic reporting. Losses provide less flexibility from the regulatory management perspective. If, however, insurers do manage losses across states to reduce regulatory pressure, the manipulation should not bias this study's estimates unless taxes and regulatory restrictions are correlated, a relation that Petroni and Shackelford (1995) fail to detect.

Finally, insurers occasionally process claims, mail refunds, and provide other bookkeeping services for large corporations that self-insure. During the period examined in this study, some insurers reported losses arising through such arrangements as "insured" losses, even though the company retained all risks. We are unable to assess the extent to which our measure

\footnotetext{
${ }^{7}$ Four states (Florida, Illinois, New Hampshire, and New York) tax the income of all insurers writing within their state. Three states (Connecticut, Kansas and Oregon) only tax the income of insurers incorporated in their state. The conclusions in this paper are insensitive to the inclusion of these states in the study.
} 
of coverage includes these self-insured losses. However, such measurement error should bias against rejecting the null hypothesis that taxes do not affect self-insurance.

\subsection{TAX}

The ideal tax measure would capture the relevant tax rate used by property-casualty insurers when they set insurance rates. Unfortunately, the data do not permit such fine calibrations. Instead we use a tax measure similar to the one in Petroni and Shackelford (1995, 1999). TAX is the sum of the total taxes collected from all insurers, both property-casualty and life and health, for the three years immediately preceding the investigated year as a percentage of the total property-casualty and life and health premiums written in each state for same three preceding years.

$T A X$ is computed using data from the three preceding years to mitigate concerns about possible endogenous relations between current taxes and other regression variables. However, inferences are qualitatively unaltered when $T A X$ is the current year's taxes divided by the current year's premiums, which is the measure used in Petroni and Shackelford $(1995,1999)$. On a separate note, $T A X$ is a flawed measure to the extent life and health insurers are taxed differently from property-casualty insurers. Petroni and Shackelford (1995). however, contend that this effect should be immaterial because states tax the two sectors similarly.

\subsection{Control Variables}

Control variables are included in the regression to mitigate the potential that omitted correlated variables may lead to erroneous inferences about the effects of state taxes on self-

insurance. POP, the state's total population, and WEALTH, gross state product per capita, are 
designed to capture cross-state differences in the demand for insurance. CAT, the state's catastrophic losses, is designed to capture cross-state differences in states of nature. Insured losses are expected to be increasing in each control variable.

\subsection{Data}

The insured losses and premiums of each U.S. property-casualty insurer are collected for each year from the NAIC Property/Casualty Annual Statement Database and summed by state. ${ }^{8}$ Each state's total taxes collected annually from insurance companies are gathered from the NAIC Insurance Department's Resources Report. The population and gross state product of each state are collected from annual U.S. Statistical Abstracts.

Estimated catastrophic losses for each year are collected from The Fact Book, an annual publication by the Insurance Information Institute. A catastrophe is defined as an occurrence that causes more than $\$ 5$ million in insured property damage. Catastrophic loss estimates are made by the Property Claim Services division of American Insurance Services Group Inc. using various sources of data, including claims adjusters and state and local officials. For those catastrophes that occurred in more than one state, estimated losses are allocated across the affected states based on their relative populations.

\footnotetext{
${ }^{8}$ Data source: NAIC, by permission. The NAIC does not endorse any analysis or conclusions based on the use of these data. The sample includes American captive insurance companies, which unfortunately we are unable to identify. To the extent captives mask self-insurance as risks transferred to third party insurers, their inclusion should bias against rejecting the null hypothesis that insurer taxes do not affect self-insurance. However, because captive insurance companies are predominantly located outside the U.S., enabling them to avoid American taxes and regulation, the inclusion of the relatively small set of domestic captives should not have a major impact on this study. In addition, data from the District of Columbia are excluded from the study because they have a disproportionate impact on the results, which we attribute to the jurisdiction's unique urbanity.
} 


\subsection{Descriptive Statistics}

Table 1 presents descriptive statistics for the regression variables in 1993. Insured losses are segregated into automobile liability losses, automobile physical damage losses, and other property-casualty insured losses because each category is tested separately in the regression analysis below. Combining the three groups, the mean insured losses are $\$ 3.3$ billion. The mean and median values for $T A X$ are 1.6 percent, ranging from 0.6 percent (Wisconsin) to 2.7 percent (Mississippi). In 1993 the mean (median) state suffered \$115 (\$47) million in catastrophic damages or 3 percent of total insured losses. Descriptive statistics for 1994 and 1995 are similar to those reported in Table 1, except that 1994 had a major catastrophe, the Northridge, California earthquake, and 1995 was relatively unscathed by catastrophes with the median state registering none.

\subsection{Univariate Analysis}

Table 2 presents Pearson correlation coefficient estimates for each of the regression variables using 1993 data expressed in natural logarithms. The correlation coefficient estimate between TAX and LOSS is negative and highly significant; however, so is the correlation between $T A X$ and POP. Because LOSS and POP are highly positively correlated, inferences about the relation between taxes and coverage must be deferred until the multivariate analysis is completed. Correlations are qualitatively similar in 1994 and 1995. 


\section{Empirical Results}

\subsection{Primary findings}

Regressions are conducted separately for the automobile lines and the other lines of business because the demand curve for automobile liability insurance is expected to be less elastic than the demand curve for other property-casualty lines. Initial tests are conducted on the non-automobile lines of property-casualty insurance where a downward sloping demand is predicted.

The regression results in Table 3 present evidence consistent with state taxes suppressing coverage for property-casualty lines, other than automobile. ${ }^{9}$ The coefficient estimates on the natural logarithm of $T A X$ are -0.24 in 1993 (significantly less than zero at the 5 percent level using a one-tailed test), -0.28 ( 1 percent significance) and -0.18 (10 percent significance). The coefficient estimates on the control variables are always positive, as predicted, and stable across years.

The TAX coefficients enable us to estimate the effects on self-insurance of a change in state tax rates. Suppose a state with a 1993 mean tax rate of 1.6 percent increases its tax rate by one standard deviation. Using the 1993's standard derivation for TAX of 0.5 percent and the mean state's 1993 non-automobile losses of $\$ 1.87$ billion, the regression coefficient estimate for 1993 implies that insured losses in the state would decrease by $\$ 140$ million, a 7.5 percent reduction in insurance coverage. ${ }^{10}$

\footnotetext{
${ }^{9}$ The regression results report standard errors and $t$-statistics using White's adjustment when the null hypothesis of correct model specification under White's (1980) test is rejected at conventional levels. Inferences are unaltered, however, if no corrections are made.

${ }^{10}$ The percentage increase in the state tax rate is 31.25 percent $(0.5 / 1.6)$. The product of 31.25 percent and the 1993 $T A X$ coefficient of -0.24 is 7.5 percent. 7.5 percent of the 1993 mean non-automobile insured losses of $\$ 1.87$ billion is $\$ 140$ million.
} 
This rough approximation provides an indication of the economic significance of the regression coefficient estimates. ${ }^{11}$ However, it ignores important general equilibrium effects, including likely responses by insurance companies, consumers, and other states to a change in tax rates. It also ignores any behavioral response to self-insurance, namely, a tendency toward increased loss prevention, reducing moral hazard concerns (Pauly, 1968).

These findings carry important social welfare implications to the extent sub-optimal risk sharing arises as residents shift to self-insurance. Among other effects, high levels of selfinsurance jeopardize a state's ability to weather catastrophic damage. Additional analysis, however, is needed to determine whether the social benefits from the tax revenue offsets the suboptimalities introduced by the taxes.

\subsection{Sensitivity tests}

The findings in this study are robust to alternative specifications and control variables. Specifically, results are insensitive to estimating equation (1) in log-linear expression. Conclusions are qualitatively unaltered when the regression variables expressed in levels are scaled by population. The $T A X$ coefficients remain negative and significantly less than zero. As expected, the adjusted $\mathrm{R}^{2}$ in the scaled models are smaller, ranging from 18 percent to 42 percent. Results also hold when equation (1) is estimated using rank regressions.

In addition, because the theory is not rich enough to identify the ideal set of control variables, a battery of estimations was conducted using alternative control variables. The results from using these controls are not reported because when they were included with the set of

\footnotetext{
${ }^{11}$ To our knowledge, prior studies have not documented the price elasticity of non-automobile property-casualty insurance. Thus, we are unable to assess the reasonableness of this elasticity estimate. See footnote 17 for a comparison of our estimates of the price elasticity of automobile insurance with those in the extant literature.
} 
control variables in equation (1), their estimated regression coefficients are not significantly different from zero and their inclusion does not affect the inferences drawn from the $T A X$ coefficients. The unreported control variables are: (a) crime rates for burglary, robbery and larceny as reported in the Uniform Crime Reports 1993-1995; (b) the 1994 cost of living index in the CQ State Fact Finder; (c) personal income per capita per the Statistic Abstract of the United States; (d) number of new business starts in the state per the U.S. Bureau of the Census' State and Metropolitan Area Data Book, (e) a Conning \& Company index of state regulatory restrictions; and (f) a categorical variable indicating whether the state must approve changes in non-automobile property-casualty insurance rates (i.e., a rate regulated state), as reported by the National Association of Insurance Commissioners in a 1992 chart entitled, "Rate filing methods for property/casualty insurance, workers' compensation, title."

The failure to detect a relation between coverage and regulation is surprising, considering the extant regulatory literature. Harrington (1984) concludes that the evidence generally is consistent with insurance rates decreasing in the stringency of state regulatory oversight, implying that coverage should be greater in rate-regulated states. Consistent with Harrington (1984), Petroni and Shackelford (1999) find that premium-loss ratios are decreasing in regulation. In addition, Vines (1996) reports that customers in rate-regulated states bore less of the industry's Federal income tax increase following the Tax Reform Act of 1986 than customers in other states, consistent with regulation introducing supply inelasticities. One reason this study may fail to detect regulatory effects is that its power (i.e., 50 states) is insufficient, given the imprecision in calibrating regulation and the aggregation of differentially regulated lines of business in a single regression model. 
One control variable whose coefficient is significantly different from zero is the maximum statutory state corporate income tax rate. An attraction of purchasing coverage for business risks is that the insured party can deduct premiums against its income taxes. Business losses arising under self-insurance also are deductible. Losses under self-insurance, however, are deducted when incurred while premiums are deducted when paid. Moreover, because selfinsurance excludes insurer profits, it provides a smaller tax deduction than purchased coverage.

Thus, self-insurance of business risks arguably is greater in states with lower income tax rates. To test this proposition, we reestimated the regression, including the maximum statutory state corporate income tax rate as reported in Commerce Clearinghouse's State Tax Handbook. The mean and median corporate income tax rate is 7 percent, ranging from zero to 12 percent with a standard deviation of 3 percent. It is negatively correlated with $T A X$, though not significantly different from zero.

Data limitations potentially introduce measurement error in this test in at least two ways. First, it is impossible to determine whether the losses (or the purchased coverage) are businessrelated and thus deductible. Second, the test presumes that the deduction offsets income in the state where the loss is incurred. In reality, determining the state in which a business can deduct expenses is governed by complex laws (e.g., apportionment factors and nexus) that are beyond the scope of this paper and not ascertainable using these data (see Klassen and Shackelford, 1998, for further details). Nevertheless, we find the coefficient on the maximum statutory corporate income tax rate is positive and significantly greater than zero in every year, consistent with self-insurance decreasing in the value of the state tax deduction. ${ }^{12}$ Inferences drawn from

\footnotetext{
${ }^{12}$ The individual income tax rate applies to self-employed, uninsured business losses. The personal tax rate, however, was excluded from these tests because state corporate and individual income tax rates are highly positively correlated.
} 
the TAX coefficients, however, remain qualitatively unaltered by the inclusion of an income tax rate. The TAX coefficients ( $t$-statistics) are $-0.21(-1.91)$ in 1993, $-0.23(-2.18)$ in 1994, and $0.18(-1.89)$ in 1995 .

Finally, conclusions are unaffected if the dependent variable is premiums earned. Recall that insured losses is selected as the dependent variable because Petroni and Shackelford's (1999) findings imply that using premiums as the dependent variable would bias toward rejecting the null hypothesis. Consistent with the expectation that results would be stronger using premiums, when premiums is the dependent variable, the $t$-statistics for the $T A X$ coefficients are slightly more negative: -2.36 in 1993,-2.90 in 1994, and -1.82 in 1995.

\subsection{Alternative explanation}

The results in this section also are consistent with an alternative explanation. Recall that Petroni and Shackelford (1999) report a disproportionate amount of premiums from multistate policies is reported as earned in low premium tax states. Suppose insurers also shift the losses associated with those premiums. ${ }^{13}$ Shifting the losses would not affect the premium tax liability, but perhaps it could mask the manipulation of the premiums. If the losses are shifted, then more insured losses are reported (though not necessary incurred) in low-tax states. If so, the relation between losses and taxes reported above is not evidence of taxes increasing self-insurance, but simply another manifestation of the premium tax avoidance found in Petroni and Shackelford (1999).

\footnotetext{
${ }^{13}$ Shifting of all losses associated with the shifted premiums is unlikely. Petroni and Shackelford (1999) examine cross-state variation in premium-loss ratios. If all losses were shifted, the ratios would not yield the cross-state variation that they present as evidence of premium tax avoidance.
} 
To test this alternative explanation requires investigating a line where manipulation of premiums is not expected. The following section examines such a setting, automobile insurance coverage.

\subsection{Automobile insurance}

As discussed above, Petroni and Shackelford (1999) document a disproportionate amount of premiums from multistate policies is reported as earned in low premium tax states. However, they find no such premium manipulation of automobile insurance premiums, which they attribute to the lack of multistate automobile policies. In other words, automobile insurance premiums are not shifted to manage taxes or regulation because automobile insurance is rarely packaged in multistate policies. Thus, the automobile premiums that insurers disclose in their annual accounting reports appear unmanaged. As a result, finding a relation between self-insurance and taxes in the automobile line would be inconsistent with the alternative explanation and increase confidence in the original interpretation of the results.

To examine automobile coverage requires dichotomizing the line into two broad classifications, liability and physical damage. As noted above, the demand curve for automobile liability insurance is expected to be less elastic than the demand curves for automobile physical insurance. ${ }^{14}$ Automobile liability insurance is strictly regulated in many states, and 39 states require motorists to carry automobile liability insurance. ${ }^{15}$ Moreover, every noncompulsory state has a system known as "financial responsibility." In those states, self-insured motorists who fail

\footnotetext{
${ }^{14}$ At least one study provides evidence that demand curves differ between liability and physical insurance. Examining the consumption patterns in 359 Massachusetts municipalities in 1979, Sherden (1984) finds that the elasticity of the demand curve for bodily injury coverage (a form of liability insurance) is less than the elasticity of the demand curves for comprehensive coverage and collision coverage (two forms of physical damage coverage).

${ }^{15}$ Liability insurance is not required in Alabama, Alaska, Iowa, Mississippi, New Hampshire, Rhode Island, South Dakota, Tennessee, Virginia, Washington, and Wisconsin.
} 
to compensate parties that they injure are prohibited from driving until they purchase insurance or can establish the wherewithal to cover future damages. As a result, few motorists in noncompulsory states are without liability coverage.

On the other hand, no states require motorists to carry physical damage insurance. Consequently, the relation between self-insurance and state taxes for physical coverage is expected to be similar to the relation documented above for non-automobile lines, unless the alternative explanation is valid.

To test both the alternative explanation and the hypothesis that the relation between selfinsurance and state insurer taxes varies with the elasticity of demand, equation (1) is reestimated twice, once with the natural logarithm of liability insured losses as the dependent variable and once with the natural logarithm of physical insured losses as the dependent variable. An inverse relation between physical losses and state taxes will be interpreted as contrary to the alternative explanation and support for the original inference that self-insurance is increasing in state taxes. A finding that the relation between liability losses and taxes is less negative than the relation between physical losses and taxes is consistent with the demand curve being more inelastic for liability insurance. Greater inelasticity for liability insurance is expected to impede a shift to self-insurance in response to higher state taxes.

Three additional control variables are added to the regression equation to capture potential sources of state variation unique to automobile insurance. DENSITY is state i's population per square mile in 1990. THEFT is state i's annual total motor vehicle thefts. Insured losses are expected to be increasing in the natural logarithms of both the density of the population and the number of automobile thefts. 
COMPULSORY is a categorical variable equaling one if automobile liability insurance is mandatory in state i. Although almost all motorists carry liability insurance in noncompulsory states, the option to self-insure is expected to introduce elasticity in the demand curve. Thus, liability insured losses are expected to be greater in compulsory states. Whether the state requires liability coverage is not expected to affect physical insured losses. Thus, the coefficient on COMPULSORY in the physical loss regression is expected to be insignificantly different from zero.

Table 4 presents summary statistics from the two automobile insurance regressions. As expected, the regression coefficient estimates on the natural logarithm of $T A X$ are negative when the dependent variable is the natural logarithm of automobile physical insured losses. The regression coefficient estimates are -0.17 in $1993,-0.18$ in 1994 , and -0.14 in 1995 . The coefficients are significantly less than zero at the 5 percent level in 1993 and 1994 and at the 10 percent level in 1995. These findings are not consistent with the alternative explanation. Instead they provide additional evidence that self-insurance is increasing in state taxes.

As in the prior results, the TAX coefficients enable us to approximate the effects on selfinsurance of a change in state tax rates. Using the same parameters as before, the regression coefficient estimate for 1993 implies that a one-half percentage point increase in tax rates lowers insured losses by $\$ 22$ million, a 5.3 percent reduction in coverage. ${ }^{16}$ As indicated above, these calculations are imprecise at best and should be interpreted with care. ${ }^{17}$

\footnotetext{
${ }^{16}$ The percentage increase in the state tax rate is 31.25 percent $(0.5 / 1.6)$. The product of 31.25 percent and the 1993 $T A X$ coefficient of -0.17 is 5.3 percent. 5.3 percent of the 1993 mean automobile physical insured losses of $\$ 420$ million is $\$ 22$ million.

${ }^{17}$ These computations are similar to the only automobile insurance elasticity estimates that we found. Sherden's (1984) Figure $1 \mathrm{~b}$ shows that at the average state price, the marginal price elasticity for comprehensive and collision automobile insurance is approximately 25 percent. This compares with the TAX coefficients in this study, which estimate price elasticity from 14 percent to 18 percent.
} 
In addition, the TAX coefficients for the physical coverage regressions are significantly less than the $T A X$ coefficients for the automobile liability coverage regressions. In fact, the liability $T A X$ coefficients are always positive, though not significantly different from zero. These findings are consistent with consumers being insensitive to upward adjustments in the cost of liability insurance because, unlike physical insurance, liability coverage is a necessary condition to operate an automobile.

Within the liability and physical groupings, the regression coefficient estimates on the control variables are stable across years. However, the coefficients are in the predicted direction and significant more often for the liability regressions. Population is always positive and highly significant for both liability and physical coverage. Wealth, population density, and thefts are always significantly positive in the liability regressions, but significantly different from zero in the physical regressions only once (density in 1993). Catastrophic damage never has explanatory power in either set of regressions, which is not surprising because catastrophes only account for a tiny fraction of all automobile claims.

As predicted, the regression coefficient estimates on COMPULSORY are always positive (significant at the 1 percent level) in the automobile liability regressions, indicating that requirements to carry liability insurance reduce self-insurance. As expected, the COMPULSORY coefficient is never significantly different from zero in the automobile physical regressions.

Finally, additional tests segregate insured physical losses between commercial and personal property. Because businesses have a lower percentage of their wealth in automobiles and their automobiles are more widely dispersed, self-insurance should be less costly for them than for individuals. If so, business insurance should be more price elastic than individual 
insurance. Untabulated results are consistent with this prediction. Specifically, the TAX coefficients for commercial losses are at least twice the TAX coefficients for personal losses. The hypothesis that the TAX coefficients are identical for commercial and personal automobile insurance can be rejected at the 5 percent level in 1993 and the 10 percent level in 1994 and 1995. $^{18}$

\subsection{Sensitivity tests}

The automobile regression results were subjected to same sensitivity tests applied to the non-automobile lines. Again, findings are robust to alternative specifications and control variables.

Results are insensitive to estimating the automobile regression equations in log-linear expression. Conclusions are qualitatively unaltered when the regression variables, other than TAX, WEALTH, and COMPULSORY, are scaled by population. The TAX coefficients remain negative and significantly less than zero in the automobile physical regression. They also are more negative than the $T A X$ coefficients in the automobile liability regressions, which are never significantly different from zero. Also, results again hold when rank regressions are employed.

The regressions also were estimated using several control variables that were discarded because their estimated regression coefficients were not significantly different from zero and they did not affect the inferences drawn from the $T A X$ coefficients. These control variables include the discarded control variables detailed in section 4.2. and a categorical variable indicating whether the state has no-fault automobile insurance, as reported by The Fact Book. Another robustness check involves substituting premiums for incurred losses in the

\footnotetext{
${ }^{18}$ These results are inconsistent with individual cultural differences across states affecting the inferences in this paper.
} 
regression equation. Recall that this study uses incurred losses as the proxy for coverage because reported premiums were expected to suffer from tax and regulatory management. Since Petroni and Shackelford (1999) document no such manipulation for automobile premiums, they should measure automobile coverage without bias.

An advantage of using premiums is that premiums are an ex-ante measure of coverage, rather than an ex-post measure like losses. Thus, no control is needed for unanticipated states of nature, such as catastrophes. However, a disadvantage of using premiums is that reported premiums include the premium tax. Thus, using premiums as a measure of coverage biases against rejecting the null hypothesis because reported premiums are greater in high premium tax states, ceteris paribus. Another possible disadvantage of using premiums is that they include insurer profits, which could vary across states if regulation or other factors create barriers to entry.

The mean premiums earned from automobile liability (physical) insurance is $\$ 1.4(0.7)$ billion. Table 5 presents summary statistics from reestimating the automobile regressions using the natural logarithm of premiums as the dependent variable and dropping $C A T$ as a control variable. As expected, the physical $T A X$ coefficients are always negative. They are significant at the 1 percent level in 1993 and the 10 percent level in 1994, but not significant in 1995 . In addition, they are always significantly less than the liability $T A X$ coefficients, which are never significantly different from zero. In brief, the premium regressions confirm the inferences drawn from the insured losses regressions. 


\subsection{Workers' compensation}

The preceding section shows that the results hold when premiums are employed as the dependent variable capturing insurance coverage. This section extends the robustness checks by employing a different dependent variable to test the relation between taxes and self-insurance of a specific line of property-casualty insurance, workers' compensation. Workers' compensation is essentially mandatory for all employers. Most states permit businesses to cover workers' compensation through private insurance, government funds, or self-insurance (assuming the business can show sufficient wherewithal).

The dependent variable in this paper's final robustness check is workers' compensation benefits paid by private carriers and government funds (i.e., sources other than self-insurance) divided by all workers' compensation payments (including self-insurance) for each state. In other words, the dependent variable captures the insured percentage of workers' compensation benefits paid for each state. As in the earlier tests, if self-insurance is increasing in insurer taxes, a negative coefficient is predicted for $T A X$.

Workers' compensation payments are collected from the Social Security Bulletin (1995). To our knowledge, data segregating property-casualty coverage between insurance and selfinsurance is limited to workers' compensation. Of the three years examined in this study, data are only available in 1993. Unlike insured losses, which includes accrued expenses, this measure is limited to cash payments. This is potentially an important distinction because workers' compensation is a long tailed line of business, i.e., benefits are paid for many years following a loss. Thus, payments in any year relate to coverage decisions made across several years. In addition, the dependent variable is measured with error because deductibles paid by employers are not classified as self-insurance, but rather included in the private carrier payment total. 
North Dakota and Wyoming are excluded from the analysis because they prohibit selfinsurance, and Texas is excluded because 1993 was the first year that it permitted self-insurance. For the 47 remaining states, the percentage of workers' compensation not covered through selfinsurance ranges from 54 percent to 92 percent with a mean (median) of 77 (79) percent and a standard deviation of 9 percent. A categorical variable (NOPRIVATE) is added to the explanatory variables to identify the four states (Nevada, Ohio, Washington, and West Virginia) that restrict coverage to self-insurance or state funds.

Table 6 presents the results from testing workers' compensation. The first column regresses the natural logarithm of incurred losses (as in the earlier tests) to establish that the workers' compensation relation between insured losses and insurer taxes is similar to the relation found when all forms of property-casualty insurance are evaluated. Catastrophic losses are excluded from the explanatory variables because they account for few workers' compensation claims. Consistent with the earlier findings, when the dependent variable is restricted to workers' compensation insured losses, the coefficient on TAX is negative and significantly less than zero ( $t$-statistic of -2.32$)$.

The second column reports the results from the sensitivity test that employs the percentage of insured workers' compensation payments. As predicted, the TAX coefficient is negative and significantly less than zero $(t$-statistic of -2.67$) .{ }^{19}$ Unlike the earlier tests, the dependent variable in this test can be expressed as a percentage because total payments, including self-insured losses, are known. However, results hold when the dependent variable is expressed as the natural logarithm of total insured workers' compensation payments ( $t$-statistic of -1.92). 
This analysis of the unique workers' compensation data provides additional evidence that self-insurance is increasing in the state taxes levied on the property-casualty insurance industry. In particular, this result shows that the conclusions drawn in this paper are insensitive to whether the dependent variable is measured on an accrual basis, such as insured losses or premiums, or a cash basis, such as payments.

\section{Closing remarks}

In summary, this paper finds self-insurance of property-casualty risks increases in state taxes. Tests are conducted assessing the relation between a state's property-casualty insured losses and its tax levy on the insurance industry. As expected, a negative relation holds for nonautomobile coverage and automobile physical damage coverage. Similar relations are detected for workers' compensation benefit payments. These findings are consistent with consumers opting to self-insure rather than bear the incidence of higher insurer taxes.

We fail to detect a negative relation for liability coverage, consistent with self-insurance not being an option to increased taxes when risk retention is too costly. In most states, selfinsurance of liability risks results in the forfeiture of the right to drive. The inelasticity of the demand for liability coverage results in consumers bearing its tax incidence. In a more positive light, few deadweight costs should arise from taxing automobile liability coverage.

To our knowledge, this is the first study to link state taxes and insurance coverage in a state. It should encourage additional investigations of the impact of subnational taxes on business activity. Such studies are warranted because U.S. businesses pay more in state and

\footnotetext{
${ }^{19}$ Delaware and Michigan are excluded from the analysis because these states have undue influence on the results based on Cook's (1977) distance criteria. When these states are included in the analysis, the TAX coefficient remains negative and significant at the 0.08 level using a one-tailed test.
} 
local taxes than in Federal taxes and the spread is widening as devolution increases state budgetary pressure. ${ }^{20}$

From a policy perspective, the findings suggest that suboptimal risk sharing results from taxing insurance products that have elastic demand. Consequently, states with lower insurer taxes (and accordingly less self-insurance) should fare better during periods of catastrophic damage than high-tax states, ceteris paribus. Additional analysis, however, is needed to assess the social welfare implication of insurer state taxes. It is beyond the scope of this study to determine whether the revenue raised from taxing insurers offsets the risk-sharing suboptimalities.

Finally, readers should interpret the inferences drawn from this study with caution for at least two reasons. One, ex-ante expectations about the coverage provided in a policy is imperfectly measured by ex-post insured losses. Two and perhaps more importantly, because the theory is not rich enough to specify the interaction among states, insurers, and consumers, the paper relies on several simplifying assumptions. They include: (a) unilateral responses by insurers, governments, and consumers; (b) exogenous state tax policy; and (c) no behavioral responses to self-insurance.

\footnotetext{
${ }^{20}$ For example, the Advisory Commission on Intergovernmental Relations reports that in 1991 corporations paid $\$ 413.7$ billion in state and local taxes compared with $\$ 181.7$ billion in Federal taxes.
} 


\section{References}

Besley, T. and H. Rosen, 1999, Sales taxes and prices: An empirical analysis, National Tax Journal LII, 157-178.

Bradford, D. and K. Logue, 1998, The effects of tax law changes on property-casualty insurance prices in D. Bradford, ed. The economics of property-casualty insurance, (University of Chicago Press, Chicago) 29-79.

Braid, R., 1987, The spatial incidence of retail sales taxes, Quarterly Journal of Economics 102, 881-891.

Chaloupka, F., R. Pacula, M. Farrelly, L. Johnston, P. O’Malley, and J. Bray, 1999, Do higher cigarette prices encourage youth to use marijuana?, NBER working paper 6939.

Cook, R., 1977, Detection of influential observations in linear regression, Technometrics 19, 1518.

Cummins, J. and M. Weiss, 1991, The structure, conduct, and regulation of the property-liability insurance industry in R. Kopcke and Randall, R, ed., The financial condition and regulation of insurance companies, 117-154.

Fox, W., 1986, Tax structure and the location of economic activity along state borders, National Tax Journal 14, 362-374.

General Accounting Office, 1995, Congress should consider changing Federal income taxation of the property-casualty insurance industry, GAO/GGD-85-10 (General Accounting Office, Washington, D. C.).

Goolsbee, A., 1999, In a world without borders: The impact of taxes on Internet commerce, University of Chicago working paper.

Gordon, R., 1983, An optimal taxation approach to fiscal federalism, Quarterly Journal of Economics 98, 567-586.

Gordon, R. and S. Nielsen, 1997, Tax evasion in an open economy: Value-added vs. income taxation, Journal of Public Economics 66, 173-197.

Grubert, H. and J. Slemrod, 1996, The effect of taxes on investment and income shifting to Puerto Rico, University of Michigan working paper.

Harrington, S. 1984. The impact of rate regulation on prices and underwriting results in the property-liability insurance industry: A survey. Journal of Risk and Insurance 51: 577623. 
Joskow, P., 1973. Cartels, competition and regulation in the property-liability insurance industry, Bell Journal of Economics and Management Science 4, 375-427.

Klassen, K. and D. Shackelford, 1998, State and provincial corporate tax planning: Income shifting and sales apportionment factor management, Journal of Accounting and Economics 25: 385-406.

Mikesell, J., Central cities and sales tax rate differentials: The border city problem, National Tax Journal 23, 206-213.

Mintz, J. and H. Tulkens, 1986, Commodity tax competition between member states of a federation: Equilibrium and efficiency, Journal of Public Economics 29, 133-172.

Olhoft, S., 1999, The tax avoidance activities of U.S. multinational corporations, unpublished dissertation, University of Michigan.

Pauly, M., 1968, "The economics of moral hazard: Comment," American Economic Review 58, 531-536.

Petroni, K. and D. Shackelford, 1999, Managing annual accounting reports to avoid state taxes: An analysis of property-casualty insurers, Accounting Review 74, 371-393.

Petroni, K. and D. Shackelford, 1995, Taxation, regulation, and the organizational structure of property-casualty insurers, Journal of Accounting and Economics 20, 229-253.

Poterba, J. 1996, Retail price reactions to changes in state and local sales taxes, National Tax Journal XLIX, 165-176.

Rappaport, N., 1994, Applied econometric essays on sales taxes and computer price indices, unpublished dissertation, Massachusetts Institute of Technology.

Sangha, B. and T. Neubig, 1994, Economic issues in the state taxation of insurance companies, 1994, Unpublished working paper (Price Waterhouse: Washington, D.C.).

Shackelford, D., 1999, The tax environment facing the wealthy, in J. Slemrod, ed., Does Atlas shrug? The economic consequences of taxing the rich, (Cambridge University Press), forthcoming.

Sherden, W., 1984, An analysis of the determinants of the demand for automobile insurance, Journal of Risk and Insurance LI, 49-62.

Sidhu, N., 1971, The effects of changes in sales tax rates on retail prices, in Proceedings of the sixty-fourth annual conference on taxation, (Columbus, National Tax Association-Tax Institute of America), 720-733. 
Slemrod, J., 1992, Do taxes matter? The impact of the Tax Reform Act of 1986, American Economic Review, 250-256.

Slemrod, J., 1990, The economic impact of the Tax Reform Act of 1986, in J. Slemrod, ed., Do taxes matter? The impact of the Tax Reform Act of 1986, (MIT Press, Cambridge, Massachusetts) 1-12.

Slemrod, J. 1996, A general model of the behavioral response to taxation, University of Michigan working paper.

Social Security Bulletin, 1995, Workers' compensation coverage, benefits, and costs—1992-93, 51-57.

Trandel, G., 1994, Interstate commodity tax differentials and the distribution of residents, Journal of Public Economics 53, 435-457.

Vines, C. 1996. Tax shifting in a regulated industry: An analysis of the property and casualty insurance industry. The Journal of the American Taxation Association 18: 48-71.

White, H., 1980, A heteroskedasticity-consistent covariance matrix estimator and a direct test for heteroskedasticity, Econometrica 48, 817-838. 
Table 1

Descriptive Statistics

50 states, 1993

\begin{tabular}{|l|c|c|c|c|c|}
\hline & Mean & Std. Dev. & Minimum & Median & Maximum \\
\hline LOSS: Automobile Liability & 1000 & 1160 & 66 & 695 & 5380 \\
\hline LOSS: Automobile Physical & 420 & 476 & 39 & 283 & 2620 \\
\hline LOSS: Other & 1870 & 2600 & 108 & 1100 & 15500 \\
\hline TAX & $1.6 \%$ & $0.5 \%$ & $0.6 \%$ & $1.6 \%$ & $2.7 \%$ \\
\hline POP & 5144 & 5680 & 470 & 3598 & 31220 \\
\hline WEALTH & 0.024 & 0.005 & 0.017 & 0.023 & 0.042 \\
\hline CAT & 115 & 216 & 0 & 47 & 1082 \\
\hline
\end{tabular}

LOSS is state i's insured losses in millions partitioned by automobile liability lines, automobile physical lines, and all other propertycasualty lines; TAX is the total insurance taxes collected in state $\mathrm{i}$ in the three preceding years (i.e., for 1993 analysis, years 1990 , 1991, and 1992) divided by the total premiums earned in state $i$ in the three preceding years; POP is the total population in thousands in state i, WEALTH is the state i's gross state product in billions scaled by POP; and CAT is the estimated losses paid in state i for catastrophes in millions. 
Table 2

Pearson correlation coefficient estimates (two-sided significance levels) for the regression variables in equation (1) 50 states, 1993

\begin{tabular}{|c|c|c|c|c|}
\hline & $\ln (\mathrm{TAX})$ & $\ln (\mathrm{POP})$ & ln (WEALTH) & $\ln (\mathrm{CAT})$ \\
\hline $\ln (\mathbf{P O P})$ & $\begin{array}{c}-0.42 \\
(0.002)\end{array}$ & & & \\
\hline In (WEALTH) & $\begin{array}{l}-0.20 \\
(0.17)\end{array}$ & $\begin{array}{c}0.02 \\
(0.89)\end{array}$ & & \\
\hline $\ln (\mathrm{CAT})$ & $\begin{array}{l}-0.21 \\
(0.14)\end{array}$ & $\begin{array}{c}0.76 \\
(0.001)\end{array}$ & $\begin{array}{l}-0.06 \\
(0.67)\end{array}$ & \\
\hline In (LOSS) & $\begin{array}{c}-0.48 \\
(0.001)\end{array}$ & $\begin{array}{c}0.96 \\
(0.001)\end{array}$ & $\begin{array}{c}0.13 \\
(0.35)\end{array}$ & $\begin{array}{c}0.76 \\
(0.001)\end{array}$ \\
\hline
\end{tabular}

See Table 1 for variable descriptions. 
Table 3

OLS regression coefficient estimates (standard errors) [ $t$-statistics]

Dependent variable: natural logarithm of non-automobile insured losses $\mathbf{n = 5 0}$ states

\begin{tabular}{|c|c|c|c|c|}
\hline & & 1993 & 1994 & 1995 \\
\hline Intercept & & $\begin{array}{c}14.84 \\
(0.98) \\
{[15.19]} \\
\end{array}$ & $\begin{array}{c}13.79 \\
(1.02) \\
{[13.43]}\end{array}$ & $\begin{array}{c}13.91 \\
(1.09) \\
{[12.71]} \\
\end{array}$ \\
\hline $\ln (T A X)$ & $(-)$ & $\begin{array}{c}-0.24 \\
(0.11) \\
{[-2.19]}\end{array}$ & $\begin{array}{c}-0.28 \\
(0.11) \\
{[-2.52]}\end{array}$ & $\begin{array}{c}-0.18 \\
(0.11) \\
{[-1.58]} \\
\end{array}$ \\
\hline $\ln (P O P)$ & $(+)$ & $\begin{array}{c}0.88 \\
(0.06) \\
{[14.88]} \\
\end{array}$ & $\begin{array}{c}0.89 \\
(0.05) \\
{[16.62]} \\
\end{array}$ & $\begin{array}{c}0.99 \\
(0.06) \\
{[17.09]} \\
\end{array}$ \\
\hline $\ln (W E A L T H)$ & $(+)$ & $\begin{array}{c}0.65 \\
(0.21) \\
{[3.16]} \\
\end{array}$ & $\begin{array}{c}0.43 \\
(0.23) \\
{[1.90]} \\
\end{array}$ & $\begin{array}{c}0.54 \\
(0.26) \\
{[2.09]} \\
\end{array}$ \\
\hline $\ln (C A T)$ & $(+)$ & $\begin{array}{c}0.07 \\
(0.03) \\
{[2.12]} \\
\end{array}$ & $\begin{array}{c}0.07 \\
(0.02) \\
{[3.17]} \\
\end{array}$ & $\begin{array}{c}0.02 \\
(0.02) \\
{[0.91]} \\
\end{array}$ \\
\hline $\operatorname{Adj} . R^{2}$ & & 0.95 & 0.95 & 0.95 \\
\hline
\end{tabular}

See Table 1 for variable descriptions. 
Table 4

OLS regression coefficient estimates (standard errors) [ $t$-statistics]

Dependent variable: natural logarithm of automobile insured losses, dichotomized by liability and physical $\mathbf{n = 5 0}$ states

\begin{tabular}{|c|c|c|c|c|c|c|}
\hline & \multicolumn{2}{|c|}{1993} & \multicolumn{2}{|c|}{1994} & \multicolumn{2}{|c|}{1995} \\
\hline & Liability & Physical & Liability & Physical & Liability & Physical \\
\hline Intercept & $\begin{array}{c}13.70 \\
(0.78) \\
{[17.61]} \\
\end{array}$ & $\begin{array}{c}11.21 \\
(0.72) \\
{[15.50]}\end{array}$ & $\begin{array}{c}13.46 \\
(0.80) \\
{[16.76]}\end{array}$ & $\begin{array}{c}10.90 \\
(0.80) \\
{[13.54]}\end{array}$ & $\begin{array}{c}13.11 \\
(0.73) \\
{[18.07]}\end{array}$ & $\begin{array}{c}10.34 \\
(0.94) \\
{[10.98]}\end{array}$ \\
\hline $\ln (T A X)$ & $\begin{array}{c}0.09 \\
(0.07) \\
{[1.21]} \\
\end{array}$ & $\begin{array}{c}-0.17 \\
(0.07) \\
{[-2.40]}\end{array}$ & $\begin{array}{c}0.07 \\
(0.08) \\
{[0.97]}\end{array}$ & $\begin{array}{c}-0.18 \\
(0.07) \\
{[-2.39]}\end{array}$ & $\begin{array}{c}0.03 \\
(0.08) \\
{[0.36]} \\
\end{array}$ & $\begin{array}{c}-0.14 \\
(0.09) \\
{[-1.61]}\end{array}$ \\
\hline $\ln (P O P)$ & $\begin{array}{c}0.89 \\
(0.05) \\
{[17.87]} \\
\end{array}$ & $\begin{array}{c}1.01 \\
(0.05) \\
{[21.84]}\end{array}$ & $\begin{array}{c}0.93 \\
(0.04) \\
{[20.88]}\end{array}$ & $\begin{array}{c}1.02 \\
(0.04) \\
{[22.81]}\end{array}$ & $\begin{array}{c}0.89 \\
(0.04) \\
{[24.38]}\end{array}$ & $\begin{array}{c}1.04 \\
(0.04) \\
{[23.11]} \\
\end{array}$ \\
\hline $\ln (W E A L T H)$ & $\begin{array}{c}0.51 \\
(0.15) \\
{[3.35]} \\
\end{array}$ & $\begin{array}{c}0.08 \\
(0.14) \\
{[0.54]} \\
\end{array}$ & $\begin{array}{c}0.49 \\
(0.16) \\
{[2.98]} \\
\end{array}$ & $\begin{array}{c}0.04 \\
(0.16) \\
{[0.26]} \\
\end{array}$ & $\begin{array}{c}0.41 \\
(0.15) \\
{[2.68]} \\
\end{array}$ & $\begin{array}{c}-0.12 \\
(0.19) \\
{[-0.63]}\end{array}$ \\
\hline $\ln (C A T)$ & $\begin{array}{c}0.01 \\
(0.02) \\
{[0.24]} \\
\end{array}$ & $\begin{array}{c}0.02 \\
(0.02) \\
{[1.08]}\end{array}$ & $\begin{array}{c}-0.01 \\
(0.02) \\
{[-0.92]}\end{array}$ & $\begin{array}{c}0.01 \\
(0.02) \\
{[0.74]}\end{array}$ & $\begin{array}{c}-0.00 \\
(0.01) \\
{[-0.23]}\end{array}$ & $\begin{array}{c}0.01 \\
(0.01) \\
{[0.80]}\end{array}$ \\
\hline $\ln (D E N S I T Y)$ & $\begin{array}{c}0.08 \\
(0.02) \\
{[3.81]} \\
\end{array}$ & $\begin{array}{c}-0.04 \\
(0.02) \\
{[-2.10]}\end{array}$ & $\begin{array}{c}0.09 \\
(0.02) \\
{[4.16]} \\
\end{array}$ & $\begin{array}{c}-0.03 \\
(0.02) \\
{[-1.44]}\end{array}$ & $\begin{array}{c}0.07 \\
(0.02) \\
{[4.07]} \\
\end{array}$ & $\begin{array}{c}-0.04 \\
(0.02) \\
{[-1.78]} \\
\end{array}$ \\
\hline $\ln (T H E F T)$ & $\begin{array}{c}0.19 \\
(0.06) \\
{[2.98]} \\
\end{array}$ & $\begin{array}{c}-0.06 \\
(0.06) \\
{[-1.02]}\end{array}$ & $\begin{array}{c}0.16 \\
(0.06) \\
{[2.64]} \\
\end{array}$ & $\begin{array}{c}-0.04 \\
(0.06) \\
{[-0.69]}\end{array}$ & $\begin{array}{c}0.19 \\
(0.05) \\
{[3.83]} \\
\end{array}$ & $\begin{array}{c}-0.01 \\
(0.07) \\
{[-0.19]}\end{array}$ \\
\hline COMPULSORY & $\begin{array}{c}0.19 \\
(0.06) \\
{[3.19]} \\
\end{array}$ & $\begin{array}{c}0.06 \\
(0.05) \\
{[1.03]}\end{array}$ & $\begin{array}{c}0.14 \\
(0.05) \\
{[2.54]} \\
\end{array}$ & $\begin{array}{c}0.05 \\
(0.05) \\
{[1.01]}\end{array}$ & $\begin{array}{c}0.14 \\
(0.05) \\
{[3.14]} \\
\end{array}$ & $\begin{array}{c}0.07 \\
(0.06) \\
{[1.07]}\end{array}$ \\
\hline $\operatorname{Adj.} R^{2}$ & 0.98 & 0.98 & 0.98 & 0.98 & 0.98 & 0.97 \\
\hline
\end{tabular}

DENSITY is state i's population per square mile in 1990; THEFT is state i's total motor vehicle thefts; COMPULSORY is a categorical variable equal to one if state $\mathrm{i}$ has compulsory liability insurance. See Table 1 for descriptions of other variables. 
Table 5

OLS regression coefficient estimates (standard errors) [t $t$-statistics]

Dependent variable: natural logarithm of automobile premiums earned, dichotomized by liability and physical $\mathbf{n = 5 0}$ states

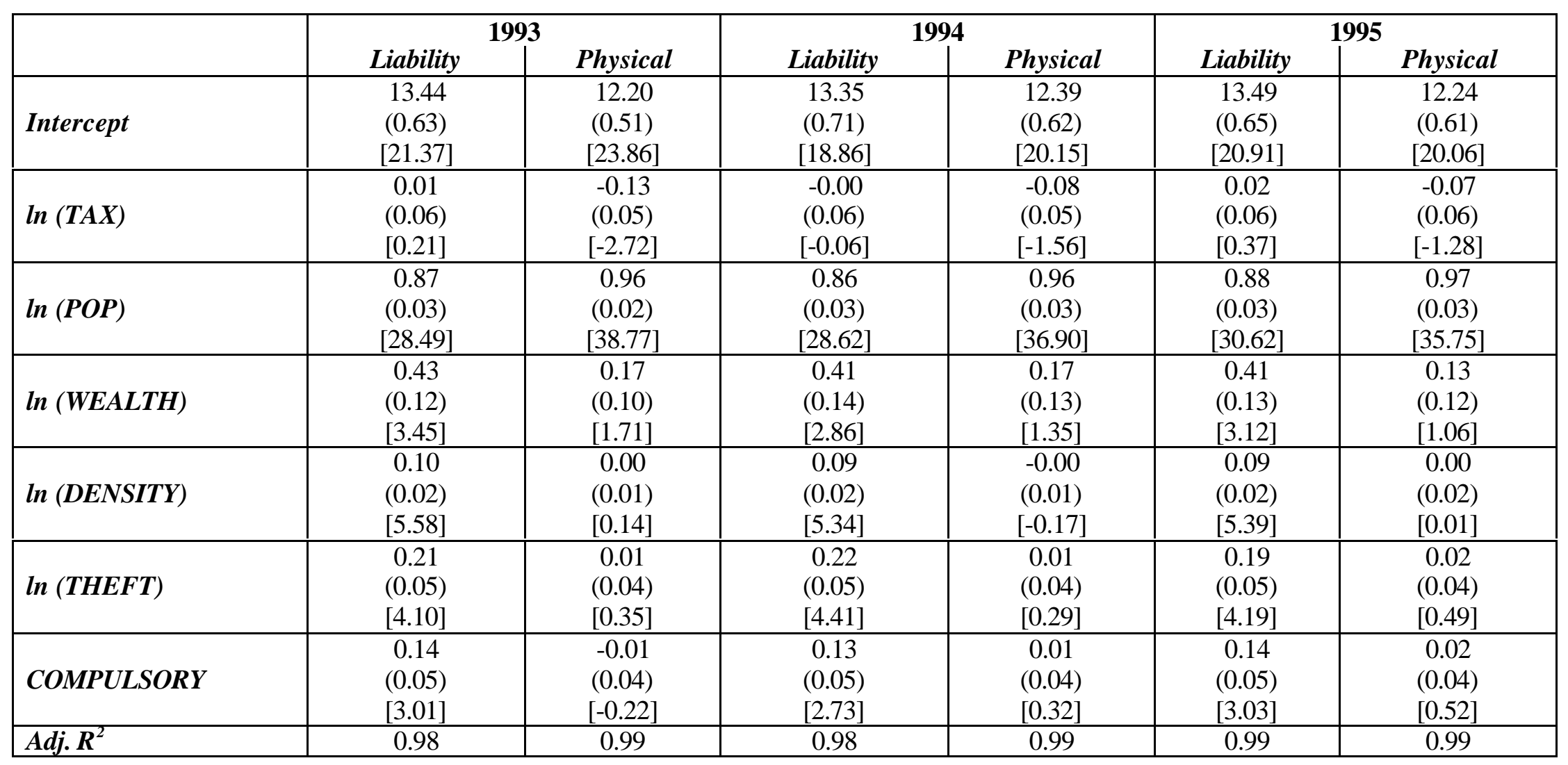

See Tables 1 and 4 for variable descriptions. 
Table 6

OLS regression coefficient estimates (standard errors) [ $t$-statistics]

Dependent variables: natural logarithm of workers compensation losses incurred in 1993 for all insurance companies and workers' compensation benefits paid by insurers as a percentage of all workers' compensation benefits paid in 1993.

\begin{tabular}{|c|c|c|c|}
\hline & & $\ln ($ LOSS) & \% paid by insurers \\
\hline Intercept & & $\begin{array}{l}14.73 \\
(1.67) \\
{[8.80]}\end{array}$ & $\begin{array}{c}0.86 \\
(0.33) \\
{[2.57]}\end{array}$ \\
\hline $\ln (T A X)$ & $(-)$ & $\begin{array}{c}-0.43 \\
(0.19) \\
{[-2.32]}\end{array}$ & $\begin{array}{c}-0.10 \\
(0.04) \\
{[-2.67]}\end{array}$ \\
\hline $\ln (P O P)$ & & $\begin{array}{c}0.81 \\
(0.08) \\
{[10.35]}\end{array}$ & $\begin{array}{c}-0.05 \\
(0.01) \\
{[-3.17]}\end{array}$ \\
\hline $\ln ($ WEALTH $)$ & & $\begin{array}{c}0.97 \\
(0.36) \\
{[2.70]}\end{array}$ & $\begin{array}{c}0.04 \\
(0.07) \\
{[0.50]}\end{array}$ \\
\hline NOPRIVATE & & $\begin{array}{c}-3.26 \\
(0.20) \\
{[-16.35]}\end{array}$ & $\begin{array}{c}0.05 \\
(0.04) \\
{[1.31]}\end{array}$ \\
\hline $\bar{n}$ & & 44 & 45 \\
\hline $\operatorname{Adj.} R^{2}$ & & 0.92 & 0.17 \\
\hline
\end{tabular}

NOPRIVATE is a categorical variable equaling one if state i does not allow private carriers to sell workers' compensation insurance. See Table 1 for descriptions of other variables. 